\title{
School-to-University Transition: The Paradox of Motivated but Undecided Students
}

\author{
Michalis Christodoulou \\ University of Patras, GREECE \\ School of Social Sciences and Humanities
}

Received: 6 January 2021 • Accepted: 18 March 2021 • Published Online: 15 April 2021

\begin{abstract}
Educational research on university transitions has repeatedly highlighted that inequalities related to cultural origin still persist even though intergenerational upward mobility has been facilitated over the last fifteen years due to the huge enrollment rates documented across countries in the Western world. In contrast to this line of research in which differences between social or cultural groups are investigated, the unit of analysis in this article is a demographically homogeneous group of families in which the parents invest in university studies as the main route for their children's post-18 pathways. Through a variable-based research design we explore the conditions which affect high-school students' motives for following university studies. The main finding has to do with the fact that it is how late or early students make their decision that is the factor differentiating the families within this group and affecting the students' transition to university.
\end{abstract}

Keywords: motives, university transition, peer-group influence, family influence, decisionmaking.

\section{Introduction. Three variants of sociologically-oriented educational research}

Since the sixties, the social-class conditions affecting the transition to higher education have constituted one of the much-debated issues in educational studies as far as the sociological and socio-psychological fields are concerned (Devine, 2004; Gambetta, 1987). The reason for this has been repeatedly highlighted and concerns the fact that holding a higher education degree impacts one's occupational, social or health status (Dudal, Verhaest \& Bracke, 2018; Morley, 2012) and that by mediating between class origin and occupational destination it can reduce (or not) the reproduction of inequalities across generations. In the last twenty years there has been an explosion in demand for higher education studies due to transformations related to the credentialization of specific jobs in the job market. In particular, according to OECD (2020: 5466), Greece:

$>$ has the fourth highest tertiary enrolment rate among OECD countries and has experienced an increase in tertiary education attainment over the last decade.

$>$ has the highest enrolment rates in bachelor's programs of all OECD countries among 19-24-year-olds, and the second highest rates among 25-28-year-olds. Overall tertiary enrolment rates for 19-20-year-olds and 21-22-year-olds are the

(C) Authors. Terms and conditions of Creative Commons Attribution 4.0 International (CC BY 4.0) apply. Correspondence: Michalis Christodoulou, University of Patras, School of Social Sciences and Humanities, Rio University Campus, Rion Achaias, Patras, GREECE. E-mail: hristodoulou@upatras.gr. 
fourth highest across OECD countries, and the rate for 23-34-year-olds is the third highest. Women make up 52\% of new entrants into tertiary education.

$>$ between 2008 and 2018, there was a noticeable increase in the share of 25-34year-olds attending tertiary education in Greece, from $28 \%$ to $43 \%$; the increase was greater among women (from $32 \%$ to $51 \%$ ) than among men (from $25 \%$ to $35 \%$ ), leading to a higher share of tertiary-educated women compared to men. Women also have a higher completion rate (81\% compared to $74 \%)$ at the bachelor's level.

These data suggest a departure from Comi's (2003, as cited by Symeonaki \& Stamatopoulou, 2014: 685) findings that Mediterranean countries, including Greece, are the most immobile in education, since the enrollment rate has increased regarding both the 2008-2018 period and women's share of tertiary education. The data seem to confirm Daouli, Demoussis and Giannakopoulos' research (2010) which found that there is substantial cross-generational educational mobility over time and that daughters seem to have a greater likelihood of upward transitions. Symeonaki and Stamatopoulou (2014) reveals that individuals' likelihood of attaining a higher educational level than that of their parents has increased in the last twenty years and that intergenerational cohort comparisons attest that upward mobility predominates over downward transitions and seems to increase over time, even though this increase has halted for the younger birth cohort.

Sociological researchers devoted to educational inequalities have demonstrated that students' university choice is the most crucial dimension not only because educational credentials are considered the major determinants of transition to the labor market but also because differences in choice patterns point out how and why class inequalities persist through the workings of cultural capital (Bunn, Threadgold \& Burke, 2019). In Greece, Sianou-Kyrgiou and Tsiplakides (2011), in examining whether and to what extent students from different socioeconomic backgrounds but with similar performance make different choices, underline the fact that the familial habitus of lower-middle-class and working- class students have explanatory power. In particular, these students "present a family-inculcated habitus of "unemployment aversion' strategy, with the assurance of permanent employment in the public sector" (SianouKyrgiou \& Tsiplakides, 2011: 94). In other research, Sianou-Kyrgiou (2010) has demonstrated that the choice of university is a process that disadvantages lower-class students while those from privileged classes with high academic performance do not simply seek entry to university but entry to the 'correct' university and make decisions about the department and subject of study on the basis of their interests and preferences. They make choices leading to elite professions and the socalled traditional professions or to modern professions with prospects of a career that will ensure the reproduction of their privileges.

In addition to intergenerational studies focusing on educational mobility and to educational studies researching inequalities, a third strand of educational research focuses on the concept of transition. In this strand, various typologies of transition have been formulated. Gale and Parker (2014) have proposed a three-part conceptualization of students' school-to-university transitions. In the first type, the transition as induction, transition is approached not as "access" but mainly as a "journey" or "pathway" the form of which is linear and attention is focused on how students encounter HE when they initially enter. In this type, the most crucial period is the students' first-year experience at university and the most studied topic is their adjustment to university culture. The second type of transitions emphasizes identity change during the transition from childhood to adulthood and explores transitions as a time in which students develop their identity as university students. This is why this kind of transition is defined as development and the metaphor that is used for describing it is "trajectory". In the third type, the main theoretical assumptions framing these two approaches to transitions are questioned. In particular, representing "student transition into $\mathrm{HE}$ as (i) a particular time of crisis, (ii) part of a linear progression, and (iii) universally experienced and normalized", is disputed because none of these 
reflects students' multifaceted and complex life experiences. Instead of presenting transitions in terms of success and failure, in the "transition-as-becoming" type, transitions are not viewed as if there is a singular HE transition but as expressing subjectivities in a flux. More recently, Coertjens et al. (2016) note that the transition from school to university concerns mainly (a) the empowerment of students' "learning identity", and (b) the extent to which they will be engaged in the university's social or cultural activities in order to build social ties with the institution. It is against this background that our research is positioned. In particular, while educational research is focused on intergenerational or cultural inequalities between groups (working classes/upper classes, or advantaged/disadvantaged groups) and research interested in university transitions is centered on specifying the explanatory links connecting initial conditions with educational outcomes by using mostly qualitative methods, we aspire to describe in a variable-oriented way how decisions for university studies are taken within a socially homogeneous group and to bring to light differences within this group.

\section{Research aims and scope}

In this study we aim to enrich the transition strand of educational research not by implementing a qualitative research design, but through specific quantitative variables. Our goal is mostly to highlight some of the parameters affecting the reasons secondary school students forge in order to frame their choice to follow university studies. We have stressed the role of family and peer influence, how strong or weak their motivations are for pursuing university studies and the time period in which their decision to invest in university studies crystallized. This is mostly a social profile of how these parameters frame students' decision making to go to university. Although quantitative, the research design isn't geared to make causal claims or see the school-touniversity transition as a linear path in which one variable leads to another and the final outcome is entry to university. On the contrary, we use variable-oriented research to bring to light the interdependence of the variables which frame an outcome that has a high degree of unpredictability, that is students' decision making regarding their transition into the university. In that sense, our research questions are:

1) To what extent do family and peer influences affect how strong or weak students' motives for following university studies will be?

2) Is the length of time it takes to decide to follow university studies related to the reasons for choosing a university and future job?

3) To what extent do students' motives for going to university affect the reasons they deploy for following university studies?

\section{Methodology}

\subsection{The sample}

Data was collected from students attending general high schools which are located in the three capital towns of the three prefectures composing the regional unit of Western Greece. The cross-sectional survey design was the research plan we put in motion ${ }^{1}$. Stratified random

\footnotetext{
${ }^{1}$ The research entitled "From high-school to university" took place under the aegis of the workshop "Educational Policy, Economy and Lifelong Learning" which is a member of the Higher Education Policy Network (http://hepnet.upatras.gr) and was self-funded. The members of the research team were (a) Dr Giorgos Aggelopoulos, Educational Sciences PhD, (b) Penny Evagelakou, Educational Sciences PhD student and (c) Dr Michalis Christodoulou, Sociologist, PhD and Assistant Teaching Staff at the Department of Philosophy, University of Patras. Research principal was Professor Giorgos Stamelos and the research lasted from spring 2018 until December 2019.
} 
sampling was the sampling method we used and we took as a sampling frame the records of secondary schools held by the administration of Western Greece. Given that our research purpose concerns the school-to-university transition, our sampling reasoning contained two steps. First, we focused only on general high schools called "Genikon Lykeion" in Greek, in which students are between 15 and 18 years old. Then, by implementing systematic random sampling for students who are in the final grade (18 years old, $11^{\text {th }}$ grade) of the senior high school, questionnaires were administered in person by visiting the schools in these three towns. Data collection lasted three months (January 2018 to March 2018) because of the distance separating the towns and of the entry requirements we had to satisfy in order to get permission to carry out the research (DeVaus, 2002: 85-100). We collected 794 questionnaires.

\subsection{Data collection method}

Data were collected through a questionnaire which was composed of seven sections. Besides the first section which contains students' demographics, the rest of the sections are related to our main conceptual constructs. In particular, the second section contained items aimed at tapping the concept "students' motives" and in which students were asked to rate their views on a five-point Likert-type scale (from "strongly disagree" to "strongly agree"). The third section contained items aimed at tapping the concept "peer-group influence" and in which students were asked to rate their views on a five-point Likert-type scale (from "strongly disagree" to "strongly agree"). Similarly, the fourth section contained items aimed at tapping the concept "family influence" and in which students were asked to rate their views on a five-point Likert-type scale (from "strongly disagree" to "strongly agree"). The items pertaining to these three conceptual constructs and the value of Cronbach $\alpha$ are presented in Table 1.

Table 1. Items for the conceptual constructs of "motives", "peer group influences" and "family influence"

\begin{tabular}{|c|c|c|c|c|c|c|c|c|}
\hline \multirow{5}{*}{ 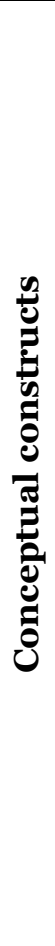 } & \multicolumn{7}{|c|}{ Number of items } & \multirow[b]{2}{*}{$\begin{array}{l}\text { Cronbach } \\
\text { a }\end{array}$} \\
\hline & & 1 & 2 & 3 & 4 & 5 & 6 & \\
\hline & Motivation & $\begin{array}{l}\text { I think } \\
\text { that } \\
\text { university } \\
\text { studies } \\
\text { are } \\
\text { extremely } \\
\text { important }\end{array}$ & $\begin{array}{l}\text { I want to } \\
\text { go to } \\
\text { university }\end{array}$ & $\begin{array}{l}\text { I think } \\
\text { that I am } \\
\text { capable of } \\
\text { going to } \\
\text { university }\end{array}$ & $\begin{array}{l}\text { I will go } \\
\text { to } \\
\text { university }\end{array}$ & & & 0.81 \\
\hline & $\begin{array}{l}\text { Peer group } \\
\text { influence }\end{array}$ & $\begin{array}{l}\text { My } \\
\text { friends } \\
\text { think that } \\
\text { I will go } \\
\text { to } \\
\text { university }\end{array}$ & $\begin{array}{l}\text { Most of } \\
\text { my } \\
\text { friends } \\
\text { will go to } \\
\text { university }\end{array}$ & $\begin{array}{l}\text { Most of } \\
\text { my } \\
\text { friends } \\
\text { think that } \\
\text { it is } \\
\text { important } \\
\text { for them } \\
\text { to go to } \\
\text { university }\end{array}$ & $\begin{array}{l}\text { Most of } \\
\text { my } \\
\text { friends } \\
\text { want to } \\
\text { go to } \\
\text { university }\end{array}$ & $\begin{array}{l}\text { Most of } \\
\text { my } \\
\text { friends } \\
\text { will try to } \\
\text { go to } \\
\text { university }\end{array}$ & $\begin{array}{l}\text { Most of } \\
\text { my } \\
\text { friends } \\
\text { think that } \\
\text { they are } \\
\text { capable of } \\
\text { going to } \\
\text { university }\end{array}$ & 0.86 \\
\hline & $\begin{array}{l}\text { Family } \\
\text { influence }\end{array}$ & $\begin{array}{l}\text { My family } \\
\text { thinks } \\
\text { that I will } \\
\text { go to } \\
\text { university }\end{array}$ & $\begin{array}{l}\text { My family } \\
\text { thinks } \\
\text { that it is } \\
\text { important } \\
\text { for me to } \\
\text { go to } \\
\text { university }\end{array}$ & $\begin{array}{l}\text { Most of } \\
\text { my family } \\
\text { members } \\
\text { hold a } \\
\text { university } \\
\text { degree }\end{array}$ & $\begin{array}{l}\text { Most of } \\
\text { my family } \\
\text { members } \\
\text { were good } \\
\text { students } \\
\text { at school }\end{array}$ & $\begin{array}{l}\text { Most of } \\
\text { my family } \\
\text { members } \\
\text { wanted to } \\
\text { study at } \\
\text { university }\end{array}$ & $\begin{array}{l}\text { Most of } \\
\text { my family } \\
\text { members } \\
\text { tried to go } \\
\text { to } \\
\text { university }\end{array}$ & 0.73 \\
\hline
\end{tabular}

The next three sections concerned students' reasons for decision making regarding the university, their preferred future job and the possibility of choosing the local university. The fifth 
section contained items aimed at tapping students' reasons for choosing a university, the sixth section contained items aimed at tapping students' reasons for choosing a future job and the final section contained items aimed at tapping students' reasons for choosing the local university ("Local" means the university which is located in the regional unit of western Greece). In all these items students are asked to rate their views on a five-point Likert type scale (from "strongly disagree" to "strongly agree"). The items pertaining to these concepts are presented in Table 2.

Table 2. Items related to students' reasons for choosing a university, for choosing a future job and for choosing the local university

\begin{tabular}{|c|c|c|c|c|c|c|c|c|}
\hline & & & & Numbe & ff items & & & \\
\hline & & 1 & 2 & 3 & 4 & 5 & 6 & 7 \\
\hline & $\begin{array}{l}\text { Students' } \\
\text { reasons } \\
\text { for } \\
\text { choosing a } \\
\text { university }\end{array}$ & $\begin{array}{l}\text { I would } \\
\text { choose a } \\
\text { university } \\
\text { which is } \\
\text { very close } \\
\text { to my home }\end{array}$ & $\begin{array}{l}\text { I would } \\
\text { choose a } \\
\text { university } \\
\text { where the } \\
\text { subject } \\
\text { areas are } \\
\text { close to my } \\
\text { scientific } \\
\text { interests }\end{array}$ & $\begin{array}{l}\text { I would } \\
\text { choose the } \\
\text { most } \\
\text { prestigious } \\
\text { university }\end{array}$ & $\begin{array}{l}\text { I would } \\
\text { choose a } \\
\text { University } \\
\text { at some } \\
\text { distance } \\
\text { from my } \\
\text { home }\end{array}$ & $\begin{array}{l}\text { I do not } \\
\text { care } \\
\text { about } \\
\text { the } \\
\text { choice of } \\
\text { universit } \\
y\end{array}$ & & \\
\hline 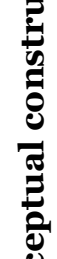 & $\begin{array}{l}\text { Students' } \\
\text { reasons } \\
\text { for } \\
\text { choosing a } \\
\text { future job }\end{array}$ & $\begin{array}{l}\text { Wage is the } \\
\text { most } \\
\text { important } \\
\text { reason for } \\
\text { choosing a } \\
\text { job }\end{array}$ & $\begin{array}{l}\text { Prestige is } \\
\text { the most } \\
\text { important } \\
\text { reason for } \\
\text { choosing a } \\
\text { job }\end{array}$ & $\begin{array}{l}\text { Self- } \\
\text { realization } \\
\text { is the most } \\
\text { important } \\
\text { reason for } \\
\text { choosing a } \\
\text { job }\end{array}$ & $\begin{array}{l}\text { My family } \\
\text { has } \\
\text { determine } \\
\text { d my } \\
\text { career } \\
\text { choice }\end{array}$ & $\begin{array}{l}\text { I do not } \\
\text { want my } \\
\text { future } \\
\text { job to be } \\
\text { tiring or } \\
\text { time- } \\
\text { consumi } \\
\text { ng }\end{array}$ & $\begin{array}{l}\text { I want my } \\
\text { future job to } \\
\text { enable } \\
\text { professional } \\
\text { advancement }\end{array}$ & $\begin{array}{l}\text { Career } \\
\text { guidance } \\
\text { lessons have } \\
\text { influenced } \\
\text { my criteria } \\
\text { for choosing } \\
\text { a job }\end{array}$ \\
\hline & $\begin{array}{l}\text { Students' } \\
\text { reasons } \\
\text { for } \\
\text { choosing } \\
\text { the local } \\
\text { university }\end{array}$ & $\begin{array}{l}\text { I would } \\
\text { choose the } \\
\text { local } \\
\text { university } \\
\text { because it is } \\
\text { close to my } \\
\text { home }\end{array}$ & $\begin{array}{l}\text { I would } \\
\text { choose the } \\
\text { local } \\
\text { university } \\
\text { because its } \\
\text { subject } \\
\text { areas are } \\
\text { close to my } \\
\text { scientific } \\
\text { interests }\end{array}$ & $\begin{array}{l}\text { I would } \\
\text { choose the } \\
\text { local } \\
\text { university } \\
\text { because my } \\
\text { friends are } \\
\text { studying } \\
\text { there }\end{array}$ & $\begin{array}{l}\text { I would } \\
\text { choose } \\
\text { the local } \\
\text { university } \\
\text { because a } \\
\text { degree } \\
\text { from } \\
\text { there will } \\
\text { never lose } \\
\text { its value }\end{array}$ & $\begin{array}{l}\text { I would } \\
\text { choose } \\
\text { the local } \\
\text { universit } \\
\text { y } \\
\text { because } \\
\text { of my } \\
\text { school } \\
\text { achieve } \\
\text { ments }\end{array}$ & $\begin{array}{l}\text { I have heard } \\
\text { that the local } \\
\text { university } \\
\text { department in } \\
\text { which I want to } \\
\text { study is one of } \\
\text { the most } \\
\text { reputable in } \\
\text { our country }\end{array}$ & \\
\hline
\end{tabular}

\subsection{Data analysis techniques}

In the next sections we will present one-variable graphs for depicting crucial information concerning the distribution of the answers in the sample for specific variables. In addition, we use Pearson chi square in order to highlight statistically significant correlations between variables which reflect tendencies in the population and simple linear regression in order to explore the intensity of the correlation. Finally, we use correspondence analysis to graphically bring to light how closely specific variables are connected.

\section{Results}

\subsection{Descriptive statistics}

The sample is composed of 383 boys (48.7\%) and 404 girls (51.3\%), students' fathers are mostly office employees (18.1\%), professionals (31.7\%), farmers (13.5\%), skilled workers 
(18.4\%), employers and executives (5\%) and unskilled workers (5\%), while students' mothers are mostly office employees (27.7\%), professionals (44.7\%), farmers (3.2\%), skilled workers (1.7\%), employers and executives (2.7\%) and unskilled workers (7.2\%). In Table 3 we present more details regarding the students' living standards.

Table 3. Students' living standards

\begin{tabular}{|l|l|}
\hline items & $\mathbf{\%}$ \\
\hline I have a personal computer & 50.7 \\
\hline Internet connection & 93.2 \\
\hline PC possession & 87 \\
\hline I have my own bedroom & 78.7 \\
\hline My parents own the house I live in & 85.2 \\
\hline I have brothers/sisters & 90 \\
\hline I have 1 brother/sister, 2, 3 or more & $57.2-27-15.5$ \\
\hline I have a maximum of 25 books at home, 26-100, over 100 & $21.5-45-34$ \\
\hline
\end{tabular}

It seems that most of the students come from families who experience a kind of safety regarding the parents' job conditions and the social milieu they grow up in. All of them grow up in four (or more)-member families in which the house belongs to their parents, they have their own bedroom, PC and internet connection. It is a sample of students whose parents, judging by the number of books at home, more or less invest in university studies as the main route for their children's post-18 pathways. In Diagram 1 we see the students' reasons for choosing university studies.

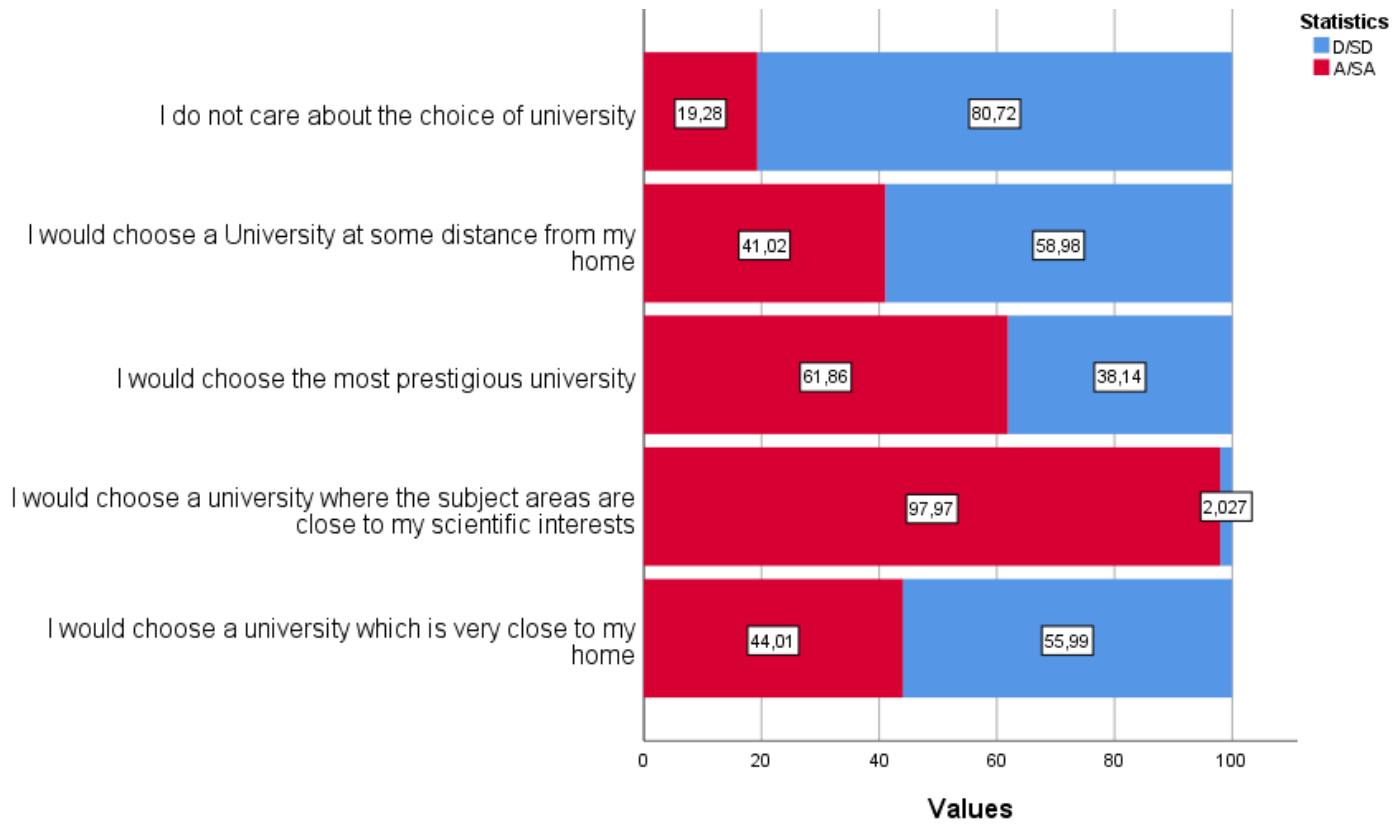

Diagram 1. Students' reasons for choosing university studies

It seems that one of the most hard-to-solve problems in their decision-making concerns the location of the university and whether it will be a university close to or distant from their home. The difficulty of this decision is intensified by the fact that students want the subject of their study to satisfy their scientific interests which, in some cases, is not possible in the university departments of the local university. In Diagram 2 we present students' reasons for choosing a future job. 


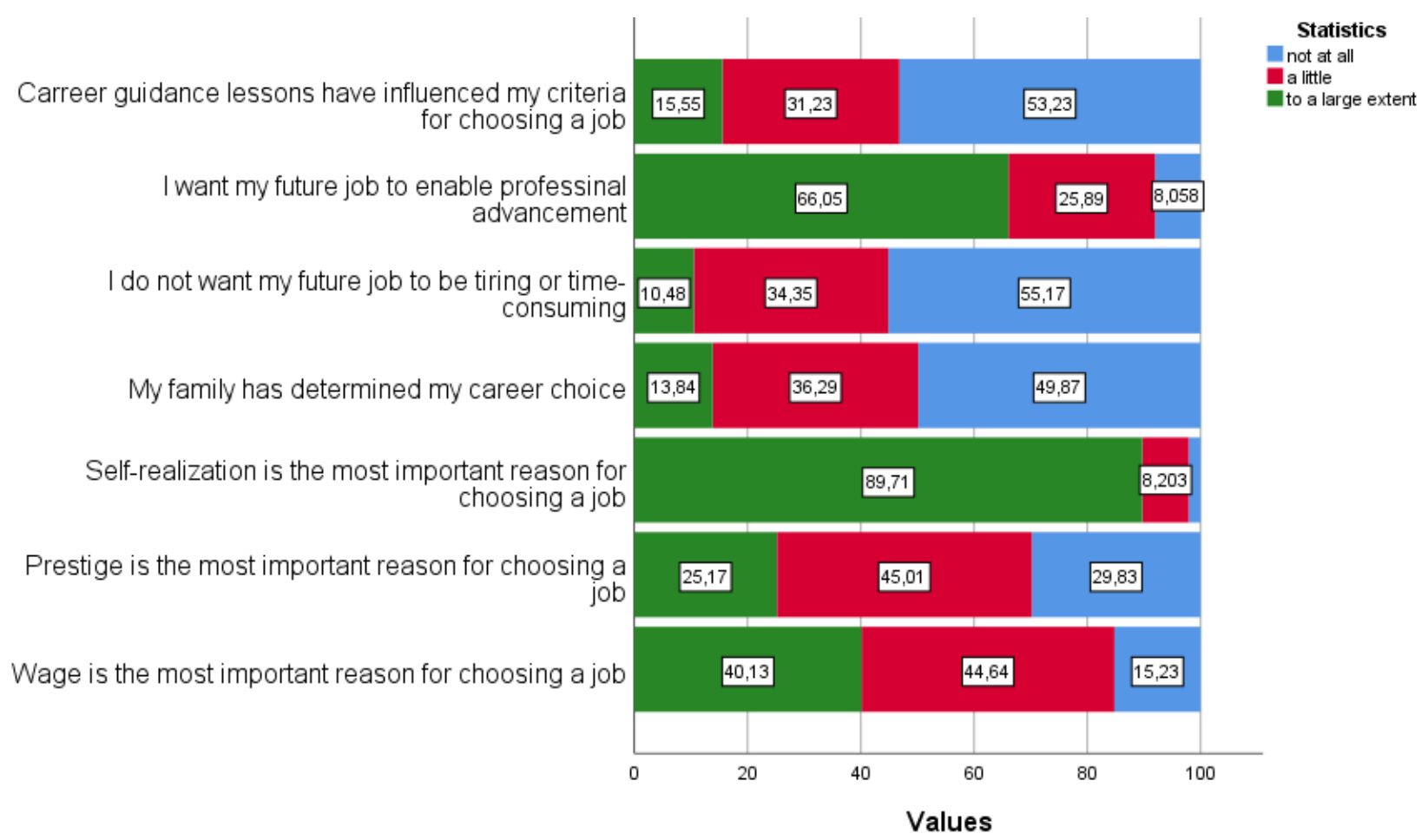

Diagram 2. Students' reasons for choosing a future job

We see that the students' choice is not affected by their schools' lessons on career guidance or by what parents expect their kids to become in the future (or they believe this is so). What matters the most has to do with self-realization or professional advancement and to a lesser extent with the prestige of the job. This finding is close to the previous one in which students want the choice of university to reflect their personal scientific interests. However, given that the local university is one of the most respected in Greece, we asked students to give reasons as to whether they would choose it. In Diagram 3 we provide students' reasons for choosing the local university.

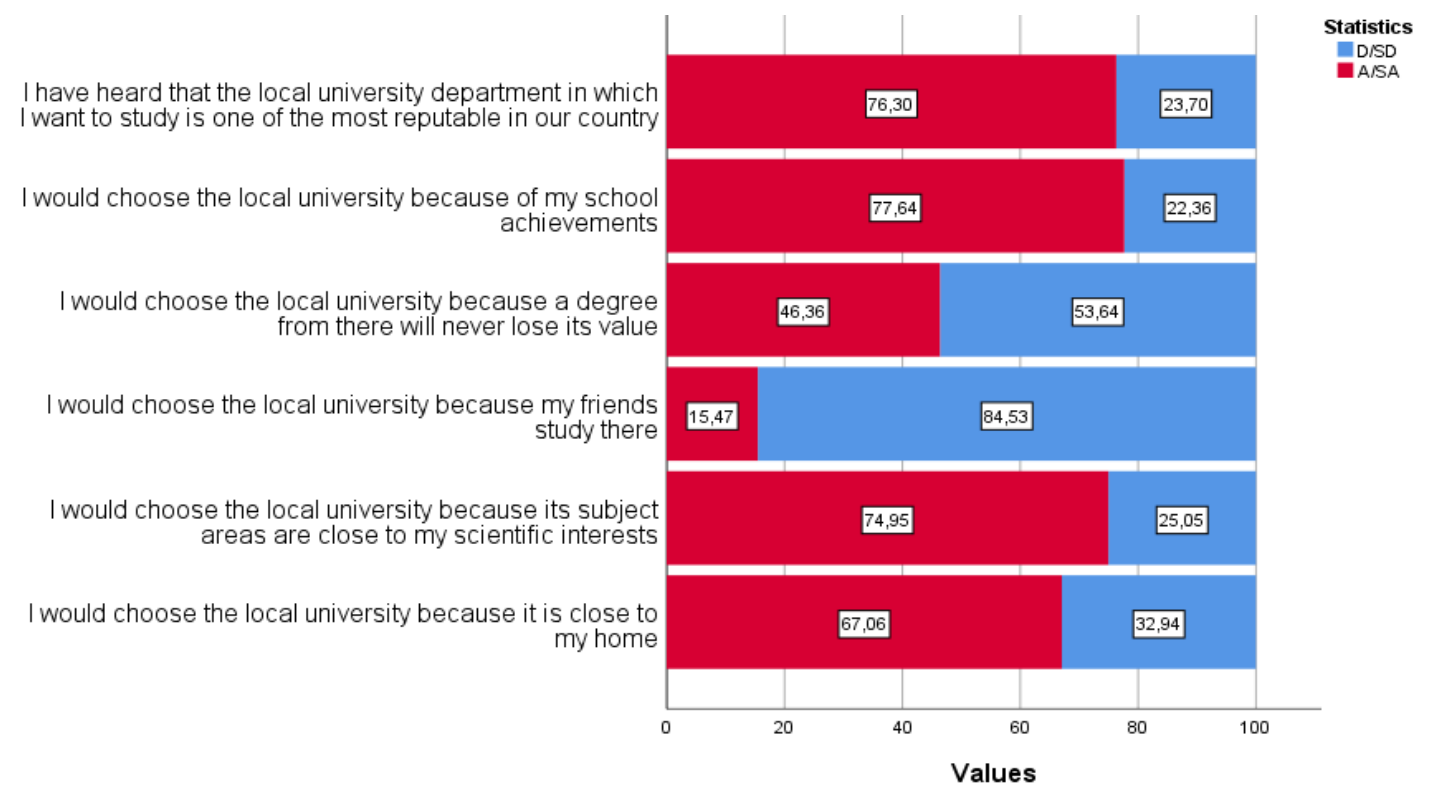

Diagram 3. Students' reasons for choosing the local university 
It is obvious that the local university attracts students not just because of its location but also because its subject areas reflect personal scientific interests or school grades, and because of its prestige and the fact that a degree from the local university will "never lose its value" in the job market. Finally, we present a variable which deserves to be separately analyzed and concerns the time period over which the students' decision regarding their post-18 plans became crystalized (Diagram 4). We have demarcated grade 9 and grade 10 as turning points because in the Greek educational system students have to decide whether they will attend vocational or general high schools before they enter grade 9 and during grade 10 they have to choose the cluster of courses (humanities or sciences) related to the scientific field they aspire to follow at university.

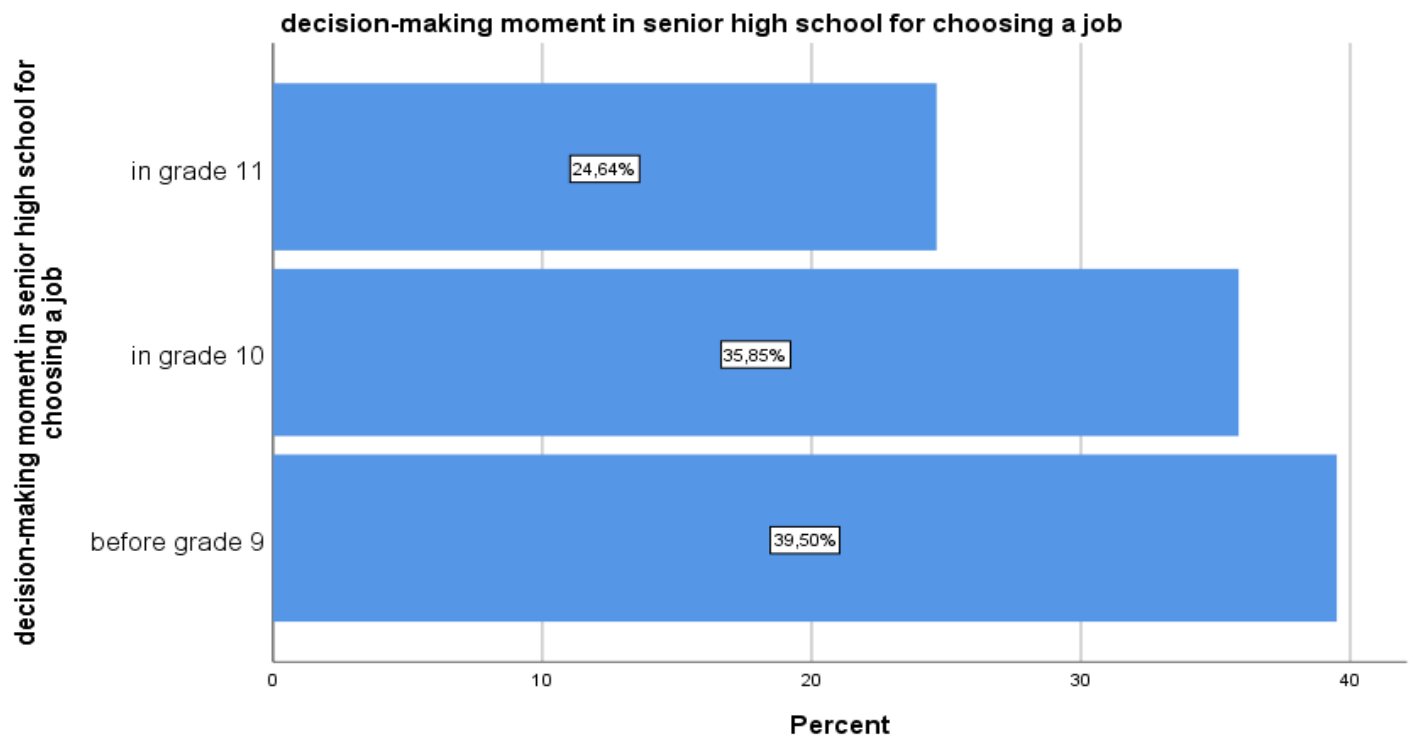

Diagram 4.

Here the important thing to note is that to a large extent (60\%) the students' decision concerning their university studies is taken too late in their school career, to be precise, when they are in $10^{\text {th }}$ and $11^{\text {th }}$ grade and are 16 or 17 years old. In the next sections we will explore possible connections between this finding and students' motives and their choice of university.

\subsection{To what extent does family and peer group affect students' motivations.}

It seems that family and peer groups act as formative influences upon students' motives. In order to explore this relation, we carried out the Pearson chi square test in two steps, first for the variable "family influence" and "students' motives" and then for "peer group influence" and "students' motives". The categories for these variables are "strong" (denoting strong influence), "neither/nor" (denoting that the influence is neither weak nor strong) and "weak" (denoting weak influence). The same holds for the "students' motives" variables. The crosstabulation for peer group influence and students' motives (Table 4) shows that there is a huge difference in the percentages of specific cells. In particular, 40\% of those with "weak" peer group influence have "weak" motives, while only $1.1 \%$ of those who have "strong" peer influence have a "weak" motive. This relation is inversed when one observes the third row. In particular, 50\% of those with "weak" peer influence have "strong" motive while 92,8\% of those with "strong" peer influence have strong motive. In addition, the correlation between these two variables is statistically significant for the population $(\mathrm{v}=175.975, \mathrm{df}=4, \mathrm{p}=0.000)$. 
Table 4. Crosstabulation of "peer group influence" and "students' motives"

\begin{tabular}{|c|c|c|c|c|c|c|}
\hline & & & Peer & group_influ & & \\
\hline & & & weak & $\begin{array}{c}\text { Neither/no } \\
\text { r }\end{array}$ & strong & Total \\
\hline Motives & weak & Count & 4 & 2 & 8 & 14 \\
\hline & & $\begin{array}{l}\text { \% within } \\
\text { Peer_group_influence }\end{array}$ & $40.0 \%$ & $3.9 \%$ & $1.1 \%$ & $1.8 \%$ \\
\hline & neither nor & Count & 1 & 23 & 42 & 66 \\
\hline & & $\begin{array}{l}\text { \% within } \\
\text { Peer_group_influence }\end{array}$ & $10.0 \%$ & $45.1 \%$ & $6.0 \%$ & $8.7 \%$ \\
\hline & strong & Count & 5 & 26 & 646 & 677 \\
\hline & & $\begin{array}{l}\text { \% within } \\
\text { Peer_group_influence }\end{array}$ & $50.0 \%$ & $51.0 \%$ & $92.8 \%$ & $89.4 \%$ \\
\hline Total & & Count & 10 & 51 & 696 & 757 \\
\hline & & $\begin{array}{l}\text { \% within } \\
\text { Peer_group_influence }\end{array}$ & $100.0 \%$ & $100.0 \%$ & $100.0 \%$ & $100.0 \%$ \\
\hline
\end{tabular}

The same holds for the variables "family influence" and "students' motivation" (Table 5). In particular, 50\% of those with "weak" family influence have "weak" motives, while only $0.5 \%$ of those who have "strong" family influence have a "weak" motive. Inversely, 35.7\% of those with "weak" family influence have "strong" motive while $94.9 \%$ of those with "strong" family influence have strong motive. In addition, the correlation between these two variables is statistically significant for the population $(\mathrm{v}=265.476, \mathrm{df}=4, \mathrm{p}=0.000)$. In other words, the more strongly family and peer group influence students' motives for their university studies, the stronger these motives are and, inversely, the weaker the influences, the weaker the motives.

Table 5. Crosstabulation of "family influence"

\begin{tabular}{|c|c|c|c|c|c|c|}
\hline & & & Influ & lence_of_Far & & \\
\hline & & & weak & neither nor & strong & Total \\
\hline Motives & weak & Count & 7 & 4 & 3 & 14 \\
\hline & & $\begin{array}{l}\text { \% within } \\
\text { Influence_of_Family }\end{array}$ & $50.0 \%$ & $3.1 \%$ & $0.5 \%$ & $1.8 \%$ \\
\hline & neither nor & Count & 2 & 36 & 29 & 67 \\
\hline & & $\begin{array}{l}\text { \% within } \\
\text { Influence_of_Family }\end{array}$ & $14.3 \%$ & $28.3 \%$ & $4.7 \%$ & $8.8 \%$ \\
\hline & strong & Count & 5 & 87 & 591 & 683 \\
\hline & & $\begin{array}{l}\text { \% within } \\
\text { Influence_of_Family }\end{array}$ & $35 \cdot 7 \%$ & $68.5 \%$ & $94.9 \%$ & $89.4 \%$ \\
\hline Total & & Count & 14 & 127 & 623 & 764 \\
\hline & & $\begin{array}{l}\text { \% within } \\
\text { Influence_of_Family }\end{array}$ & $100.0 \%$ & $100.0 \%$ & $100.0 \%$ & $100.0 \%$ \\
\hline
\end{tabular}

However, this statistically significant relation does not enlighten us regarding the intensity of the impact of peer group and family influence (independent variables) on students' motives (dependent variable). In order to explore this issue, we implemented linear regression with the method "enter". Model summary (Table 6) shows that the two independent variables have a moderate effect (0.64) on the dependent variable and that $41 \%$ of the variance in the "students' motives" variable is explained by the independent variables.

Table 6. Model summary

\begin{tabular}{ll|c|c|c} 
Model & R & R Square & $\begin{array}{c}\text { Adjusted R } \\
\text { Square }\end{array}$ & \multicolumn{2}{c}{$\begin{array}{c}\text { Std. Error of the } \\
\text { Estimate }\end{array}$} \\
\hline 1 & $.646^{\mathrm{a}}$ & .418 & .416 & 2.15705 \\
\hline a. Predictors: (Constant), Family_Influence, Peer_influence
\end{tabular}


The value of the $\mathrm{F}$ test $(\mathrm{F}=266.588, \mathrm{p}=.000<0.05)$ shows that these findings reflect what happens in the population and Table 7 shows that there is no difference regarding the weight each independent variable exerts upon the dependent (Beta=0.27 for both "peer group influence" and "family influence").

Table 7. Coefficients

\begin{tabular}{|c|c|c|c|c|c|c|}
\hline \multirow{2}{*}{\multicolumn{2}{|c|}{ Model }} & \multicolumn{2}{|c|}{$\begin{array}{l}\text { Unstandardized } \\
\text { Coefficients }\end{array}$} & \multirow{2}{*}{$\begin{array}{c}\text { Standardized } \\
\text { Coefficients } \\
\text { Beta } \\
\end{array}$} & \multirow[b]{2}{*}{$\mathrm{t}$} & \multirow[b]{2}{*}{ Sig. } \\
\hline & & $\mathrm{B}$ & $\begin{array}{l}\text { Std. } \\
\text { Error }\end{array}$ & & & \\
\hline \multirow[t]{3}{*}{1} & (Constant) & 3.587 & .563 & & 6.374 & .000 \\
\hline & Peer_influence & .276 & .023 & .367 & 11.922 & .000 \\
\hline & Family_Influence & .279 & .021 & .402 & 13.054 & .000 \\
\hline
\end{tabular}

a. Dependent Variable: Motivation

In other words, both family and peer group are related in a statistically significant and linear way to the students' motivation. The stronger the influences, the more powerful the students' motives are for attaining a university degree. However, this relation is not too intense which means that one cannot predict that whenever a strong or weak influence prevails, the motivation of students will be strong or weak respectively.

\subsection{The decision-making period and the reasons for choosing a university and future job.}

What does it mean for an adolescent when he decides late (or early) on his/her post18 life plans? Given that $2 / 3$ of the sample decide after $10^{\text {th }}$ grade (16 or 17 years old), we think that this variable deserves separate examination. By focusing only on statistically significant relations of the variable "decision-making period" with students' reasons for choosing a university and a future job, we implemented a correspondence analysis in order to show graphically how closely the variables are connected. Graph 1 shows that those who have decided before grade 9 about their university studies do not consider the location of the university to be an important factor in their decision and, inversely, those who agree that whether the university is close to their home matters, are $11^{\text {th }}$ grade students.
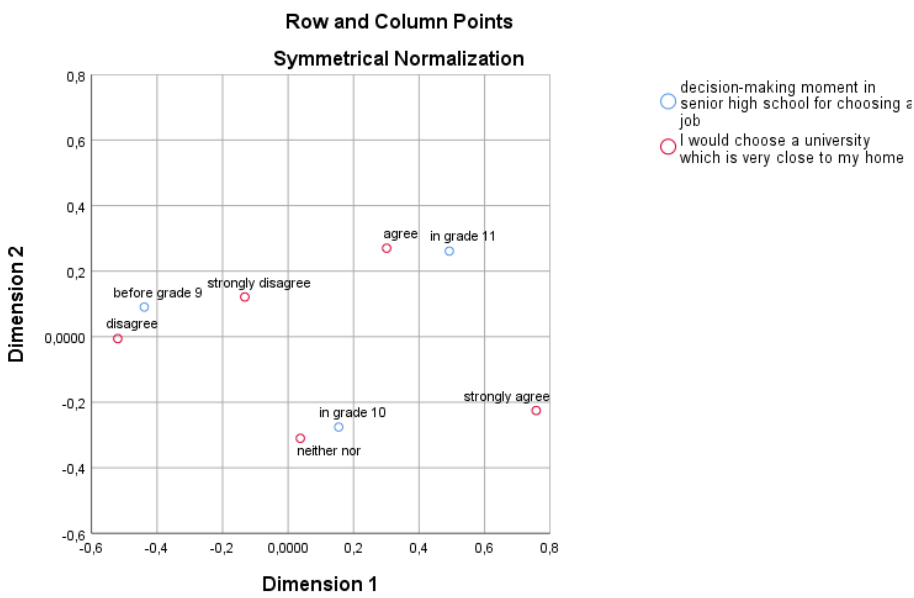

Graph 1.

In addition, it seems that self-realization matters most as a reason for choosing a future job for those who have taken this decision before grade 9, while those who take this decision 
during grade 11 do not reason that self-realization matters when selecting their future job (Graph 2).

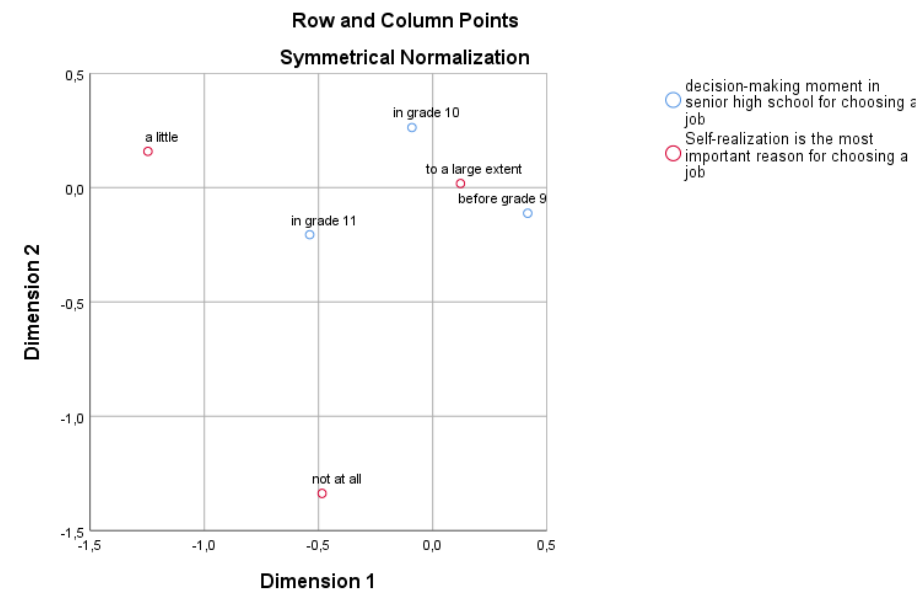

Graph 2.

Finally, a non-tiring and relaxed future job matters for those who have decided during grade 11 but it is not relevant for those who have taken this decision before grade 9 or grade 10 (Graph 3).
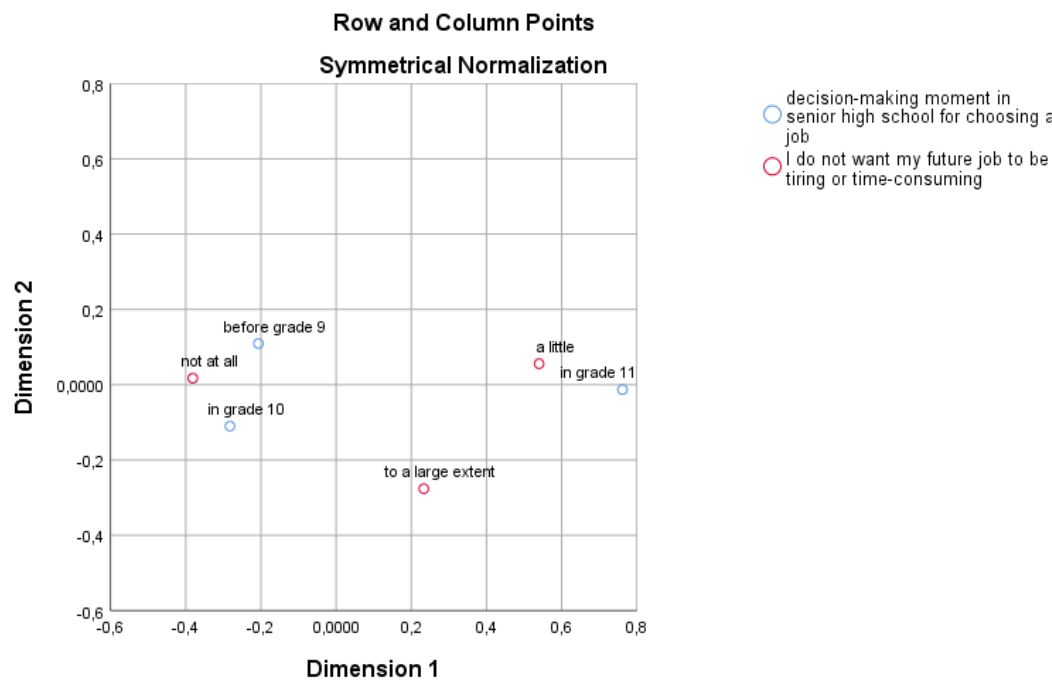

Graph 3.

In other words, for those whose decision on their future job has been taken before grade 9, the location of the university does not matter but they put emphasis on how the future job will satisfy personal interests. On the contrary, those who take this decision after grade 10 and mostly during grade 11 prioritize how close to their home the university will be and are indifferent to self-realization. This finding is confirmed by the fact that $11^{\text {th }}$ grade students care about finding a non-tiring and relaxed future job, while this is something irrelevant for those who have decided on their future job before grade 9. These findings highlight the fact that the moment of decision informs us about the students' motives in the sense that the earlier the decision for post-18 routes is made, the more committed students are to their motives and the less their motives are affected by external or ephemeral reasons. 


\section{Discussion}

Given that in Greece there are no "elite" universities like "Oxbridge”, families in Greece aspire for their children to get a degree from any university and for that reason their influence puts pressure on students' motives (Byrom, Thomson \& Gates, 2007). In that sense, what matters in the case of Greece is not so much "university choice" as how students come to take decisions regarding their post-18 life plans or how a university degree reflects their self-conception. This is close to what happens in other cases (e.g., Spruyt \& Kuppens, 2015) in which education serves as a status marker based on perceived competence. What matters are not specific educational credentials but the position people occupy in the hierarchy of the highly and the not so highly educated. The fact that the university's prestige is one of the main reasons that the students in our sample choose a university supports this line of research.

This is not to say that cultural capital is not a difference maker but that one has to explore the intermediate mechanisms through which this capital frames students' decisionmaking. However, we have shown that the students in our sample care about the prestige of the university they aspire to study at even if they are uninformed about the details of what "prestigious university" means, as the high percentages of indecision attest. In addition, given that our sample is composed of students whose parents' cultural capital predisposes them for university studies, one has to examine how this decision is formed within a group which is "homogeneous", as we have shown from the main demographic findings. In other words, our findings concern withingroup differences, not between group.

We believe that the main finding of our research has to do with the fact that while students are highly motivated to follow university routes, most of them remain undecided even during the last grade of their school trajectory. This means that most of the students' parents, although culturally educated, don't have the resources to inform their kids' decision making. It has been underlined that the more informed the decision making for university studies is, the more successful the adjustment. A smooth adjustment to the "learner identity" of the university may concern either how students connect high-school friendships with new friends at university or how neophytes become familiar with the discourse of the university (Yorke \& Thomas, 2003; Pascarella \& Terenzini, 2005). Undoubtedly, cultural capital differences play a significant role in this process since, for some students, university is a "natural development" while others are in need of encouragement or counselling in order to create a future self as a "university student" (Byrom, 2009).

Besides family influences, sociologists of education as early as the 90's highlighted how peer groups act as an intermediate mechanism in decision-shaping. Brooks (2003) has brought to light the importance of the nature of intimacy in the extent to which students will disclose personal hopes, fears and plans about their future selves to their friends. One of the puzzling findings concerns the fact that adolescents do not talk with their friends about their university aspirations. Instead of taking this finding as proof of decision making being an individualized issue, Brooks suggest that hierarchical differences within peer group friendships block students' self-disclosure. Such kinds of differences might be created either by means of students' school grades or by means of the type of university they would like to attend (for example social sciences or humanities) or they might concern the fact that some students are in different phases in the process of decision making (some are preoccupied while others are not). These remarks are in line with the finding of our research that strong peer group pressures can predict neither students' motivation nor how certain they are about their university choice.

Since schools act as important developmental contexts for the academic and socioemotional development of late adolescents it follows that the degree of affiliation that students feel towards university and school belongingness are linked to higher academic motivation (Pittman \& Richmond, 2008). Our research extends this line of inquiry because it 


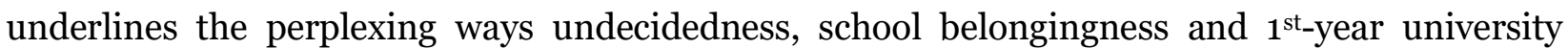
adjustment are connected. We think that research has to take account of the fact that even if school belongingness is a good predictor of social adjustment, undecidedness might undermine this relation. The reason is that should the undecidedness be prolonged during the first year at university, then university adjustment is at stake because students are not sure about their choice regarding, for example, the subject matter of their studies or the town in which university studies will take place. It is obvious that the more undecidedness is prolonged the more students will face difficulties related to forming new friendships, dealing with course workload or other university requirements and the more demanding the university transition will be. This is a hypothesis supported by McGhie (2016) who states that successful adjustment presupposes not only encouragement received from their families and friends but that students be knowledgeable as to what university study entails. An additional implication of undecidedness concerns the fact that it may block students' agency conceived as either life plans competence or self-efficacy. This is verified by Millman and McNamara (2018) whose research has shown that the determination to act in an agentic way in challenging situations (such as the decision about university studies) is put in jeopardy whenever one is uncertain about his goals. Besides the fact that undecidedness puts students' first-year adjustment to the university in jeopardy and blocks their agency, it differentiates them in relation to how they approach university studies. In particular, the more undecided one is, the more he/she prefers closeness to home as a reason for choosing university and the more he/she tends to prefer a non-tiring and relaxing future job. Conversely, the earlier the decision is made, the more probable it is that self-realization will be provided as a reason for choosing a future job.

\section{Conclusion}

In this article we investigated the extent to which family and peer influences affect the strength of students' motives for following university studies and the relevance of the time period during which students decide to pursue university studies. In Greece, the students' decision is framed in relation to three basic challenging issues: the prestige of the university, its location and the alignment of personal scientific interests with university subject areas. This is in line with the fact that professional advancement, self-realization and how close or distant the university is, are the most prominent reasons for choosing a future job and the local university respectively. However, the core finding of our research concerns the fact that the group we researched, although homogeneous regarding these parameters, presented specific socially meaningful differences. In particular, even though family and peer group influences are highly correlated with students' motives, it seems that the time period in which students take decisions makes a difference since two out of three students remain undecided even when they reach grade 11 . In other words, a paradox sustains Greek students' school-to-work transition because, although strongly motivated to follow university studies, they are highly undecided. This is a finding which differentiates the students of our group and which has to be taken seriously because it may put in jeopardy students' first-year adjustment to university and block their agency even when their transition has been realized.

\section{Acknowledgements}

This research did not receive any specific grant from funding agencies in the public commercial, or not-for-profit sectors.

The author declares no competing interests. 
References

Bunn, M., Threadgold, S., \& Burke, P. J. (2019). Class in Australian higher education: The university as a site of social reproduction. Journal of Sociology, 1-17. https://doi.org/10.1177/1440783319851188

Brooks, B. (2003). Discussing higher education choices: Differences and difficulties. Research Papers in Education, 18(3), 237-258. https://doi.org/10.1080/0267152032000107310

Byrom, T., Thomson, P., \& Gates, P. (2007). 'My school has been quite pushy about the Oxbridge thing': Voice and choice of higher education. Improving Schools, 10(1), 29-40. https://doi.org/10.1177/1365480207073718

Byrom, T. (2009). 'I don't want to go to a crummy little university': Social class, higher education choice and the paradox of widening participation. Improving Schools, 12(3), 209-224. https://doi.org/10.1177/1365480209348819

Coertjens, L., Brahm, T., Trautwein, C., \& Lindblom-Ylänne, S. (2016). Students' transition into higher education from an international perspective. Higher Education. https://doi.org/10.1007/s10734-016-0092-y

Comi, S. (2003). Intergenerational mobility in Europe: Evidence from ECHP. Paper published by Centre for Household, Income, Labour and Demographic Economics, Italy. http://www.childcentre.unito.it/papers/child18 2004.pdf

Daouli, J., Demoussis, M., \& Giannakopoulos, N. (2010). Mothers, fathers and daughters: Intergenerational transmission of education in Greece. Economics of Education Review, 29(1), 83-93.

DeVaus, D. (2002). Surveys in social research, $5^{\text {th }}$ ed. London: Routledge.

Devine, F. (2004). Class practices. How parents help their children get good jobs. Cambridge: Cambridge University Press.

Dudal, P., Verhaest, D., \& Bracke, P. (2018). Educational inequalities in depression: Do labor markets matter? Society and Mental Health, 8(2) 93-107. https://doi.org/10.1177/2156869317713553

Gale, T., \& Parker, S. (2014). Navigating change: A typology of student transition in higher education. Studies in Higher Education, 39(5), 734-753. https://doi.org/10.1080/03075079.2012.721351

Gambetta, D. (1987). Were they pushed or did they jump? Individual decision mechanisms in education, Cambridge: Cambridge University Press.

Millman, T., \& McNamara, J. (2018). The long and winding road: Experiences of students entering university through transition programs. Student Success, 9(3), 37-49.

Morley, L. (2012). Researching absences and silences in higher education: Data for democratization. Higher Education Research \& Development, 31(3), 353-368. https://doi.org/10.1080/07294360.2011.63438

McGhie, V., (2016). Entering university studies: Identifying enabling factors for a successful transition from school to university. Higher Education. https://doi.org/10.1007/s10734-016-0100-2 
OECD (2020). Education at a glance 2020: OECD indicators. OECD Publication, Paris.

Pascarella, E. T., \& Terenzini, P. T. (2005). How college affects students: A third decade of research. San Francisco, CA, Jossey-Bass.

Sianou-Kyrgiou, E., \& Tsiplakides, I. (2011). Similar performance, but different choices: Social class and higher education choice in Greece. Studies in Higher Education, 36(1), 89102. https://doi.org/10.1080/03075070903469606

Sianou-Kyrgiou, E. (2010). Stratification in higher education, choice and social inequalities in Greece. Higher Education Quarterly, 64(1), 22-40, https://doi.org/10.1111/j.14682273.2009.00427.x

Spruyt, B., \& Kuppens, T. (2015). Warm, cold, competent or incompetent? An empirical assessment of public perceptions of the higher and less educated. Current Sociology, 63(7), 1058-1077. https://doi.org/10.1177/0011392114554843

Symeonaki, A. M., \& Stamatopoulou, A. G. (2014). Exploring the transition to higher education in Greece: Issues of intergenerational educational mobility. Policy Futures in Education, 12(5), 681-695.

Yorke, M., \& Thomas, L. (2003). Improving the retention of students from lower socio-economic groups. Journal of Higher Education Policy and Management, 25(1), 63-74.

Pittman, D. L., \& Richmond, A. (2008). University belonging, friendship quality, and psychological adjustment during the transition to college. The Journal of Experimental Education, 76(4), 343-362. https://doi.org/10.3200/JEXE.76.4.343362 
M. Christodoulou - School-to-University Transition: The Paradox of Motivated but Undecided Students

C O A $\mathrm{s}$ 